\title{
Examining Risk-Weighted Assets (RWA) Performance after Recent Financial Crisis in Malaysian Banking System
}

\author{
Siti Nor Amira Mohamad ${ }^{1}$, Mohamad Yazis Ali Basah ${ }^{1} \&$ Muhammad Ridhwan Ab Aziz $^{1}$ \\ ${ }^{1}$ Faculty Economics and Muamalat (FEM), Universiti Sains Islam Malaysia (USIM) Bandar Baru Nilai Negeri \\ Sembilan, Malaysia \\ Correspondence: Siti Nor Amira Mohamad, Faculty Economics and Muamalat (FEM), Universiti Sains Islam \\ Malaysia (USIM) Bandar Baru Nilai Negeri Sembilan, Malaysia. Tel: 601-3236-9853. E-mail: \\ sitinoramira.usimfem@gmail.com
}

Received: February 1, 2018

Accepted: March 27, 2018

Online Published: April 10, 2018

doi:10.5539/ijef.v10n5p129

URL: https://doi.org/10.5539/ijef.v10n5p129

\begin{abstract}
Until recently, there has been only muted debate on the stability of RWA and after the recent financial crisis, the new regulatory framework was introduced that will enrich the quality and level of capital ratios for the banking system. However these capital ratios required to be based on specific risk measurement that permits for appropriate comparison as these gives new prominence to the stability of the underlying RWA. The aim of this paper is to examine the RWA performance after recent global financial crisis in Malaysian banking system. The study uses quantitative approach to examine in detail the RWA performance from year 2012 to 2016 using secondary analysis of bank's annual report.
\end{abstract}

Keywords: Risk-Weighted Assets (RWA), risk management, global financial crisis, banking system

\section{Introduction}

The effect of recent global financial crisis in 2008 pointed out the efficiency of RWA and the target capital adequacy ratios of banks since it has exposed variety of weaknesses in banking regulation (Lessambo, 2013). It is impacts the banking system to lose cash on loan or financing defaults and interbank lending to freeze. Besides, the effect of global financial crisis towards the performance of RWA almost due to inappropriate risks management practices and strategies (Gallati, 2003). With the recommended to at least equal to 8 percent of RWA from Basel Accord II, it is important to prevent a bank's bankruptcy and the negative externality of a financial crisis. To extent this further, with updated Basel Accord III proposed on higher quality forms of capital, but makes limited advances in risks measurement.

The important of RWA makes the banking system valuable since it can enhance capital adequacy ratios by increasing the total of regulatory capital held or by reducing the RWA (Martin Neisen, 2017). From the lesson learned in the financial crisis highlighted that there was a lack of high quality capital and it was required to entail more capital so that the trading book requirement system was better prepared for future crises.As concern on Malaysian banking system towards the recent financial crisis, the country was not segregated from the global economic downturn. This shows that the GDP performance is moderate to $0.1 \%$ in year 2008 to 2011. The central bank of Malaysia (BNM) has taken pre-emptive measures of fiscal stimulus measures, as to sustain access to financing and alleviate any effect of the heightened risk-aversion by alleviating the domestic economy and its subsequent recovery in the second half of the year with growing by $4.4 \%$. Therefore, capitalization level of the banking system in Malaysia was at its maximum historical level at the onset of the global financial crisis. The RWA performance and the core capital ratio (CCR) of the banking system in Malaysia remained above 12\% throughout the year of the crisis and the returns were also maintained at an average of $1.6 \%$.

The objective of this paper is to examine the stability of RWA performance after recent global financial crisis in Malaysian banking system by investigating in detail the RWA performance from year 2012 to 2016 using secondary analysis of bank's annual report simultaneously. We proposed to estimate a model of RWA that include equation structure as based of analysis.

This paper presents two main contributions to the empirical literature in the field of RWA of banking system. First, this paper conducts the empirical examination of the RWA performance in Malaysia. We test the 
comparison of RWA performance between Islamic banks and conventional banks in Malaysia. We assume that banks with low risks taken have good RWA performance. Second we examine simultaneously the minimum and maximum level of RWA between both types of banks from year 2012 to 2016. In this study, we assume that high returns of banks affect the level of RWA within banks. We test the minimum and maximum level between both types banking system. We hypothesize that banks with maintaining the level of RWA performance within years take higher risk.

The rest of the paper is organized as follows. Section 2 presents the literature review. Section 3 describes the empirical methodology. Section 4 describes the data used and presents the analysis. Section 5 presents the results of estimations. Section 6 concludes the paper.

\section{Literature Review}

The needs of capital adequacy framework in banking system has become one of the necessities in approaching stabilize risk-weighted assets performance. Its needs also would increase the values and profits of banks and make them resilient to crisis. Conversely, the effectiveness of RWA performance in attaining comprehension of banking system remains to be debatable especially for Islamic banks.

To date, empirical research in capital adequacy of RWA failed to convince that the RWA performance is approaching debatable between Islamic banks and conventional banks In Malaysia. One of the reasons given is that the low effectiveness arising from the management of risks associated, thus affects the performance of Islamic banks as well. Louati et al. (2015) stated that it is a significant impact of funding ratios on the behavior of conventional banks and Islamic banks includes the sample data from Malaysian banking system. But, there is no significant effect on the relationship between the RWA and Islamic bank behavior as this type of banks is applying theoretical models based on the interest-free activities.

In terms of risks and efficiency, there is the significant effect of financing to deposit ratio, capital adequacy ratio, operating expenses to operating income ratio and size on the performance of Islamic banking in contrast to the reserve requirement and non-performing financing that had no significant effect on the performance of Islamic banking (Sutrisno, 2016).

Al-Hares et al. (2013) conducts study on the financial performance and quality capital with different types of banking system. The study deliberates the extent to which different types of banking system comply with the new Basel III requirements of raising better-quality capital. It is found that Islamic banks have been affected contrarily by the global financial crisis than conventional banks.

Chazi and Syed (2010) examine how Islamic banks dealt with the recent financial crisis in terms of risk management. The capital ratios are the primary tools used to analyze the riskiness of the banking system. The finding shows that Islamic banks are maintaining better capital ratios than to conventional banks. It is a new approach to the comparative performance of banking system in terms of risk management.

Furthermore, empirical evidences on the impact of financial shocks on the Islamic banks vis-a-vis the conventional banks during the 1997 Asian financial crisis and 2007 financial crisis shows that both the Islamic and conventional banking systems are susceptible to global financial crisis. This is contrary to the popular belief that the Islamic financial system is sheltered from the financial shocks due to its interest-free nature (Kassim \& Abd. Majid, 2010).

Beck et al. (2013) show how different are Islamic banks from conventional banks in terms of efficiency and stability. It is found that there are few significant differences in business orientation and Islamic banks are less cost-effective, but have a higher intermediation ratio, higher asset quality, better capitalized and less likely to disintermediate during crises.

Das and Sy (2012) examine how shareholders account for the riskiness of banks' RWA. The results show that banks with lower RWA achieved better during the crises. Investors paid less attention to RWA and rewarded instead lower wholesale funding and better asset quality as for large banks size. RWA do not predict market measures of risk even though there is indication of a positive relationship before the crisis which becomes negative afterwards.

Tabash and Dhankar (2014) examine the influence of global financial stuck on the key performance ratios of Islamic banks by using trend analysis method. The liquidity and capital adequacy ratios are determined and it shows that Islamic banks are more stable sector in terms of, capital adequacy, and liquidity.

Rosman Wahab and Zainol (2014) examine the effectiveness level of Islamic banks during the global financial crisis precisely in Middle Eastern and Asian countries. The results clarify that Islamic banks were able to sustain 
operations through the crisis. It is also found that both profitability and capitalization were the main factors of Islamic banking effectiveness.

Although there were researches on capital adequacy in relation with risk-weighted assets (RWA), the studies were not comprehensive. None of the above aforementioned studies were comprehensive enough to cover the stability of RWA performance after recent global financial crisis in Malaysian banking system.Therefore, this paper further to fill the gap of the previous researches to presents two main contributions to the empirical literature in the field of RWA of banking system. First, this paper conducts the empirical examination of the RWA performance in Malaysia. We test the comparison of RWA performance between Islamic banks and conventional banks in Malaysia. We assume that banks with low risks taken have good RWA performance.Second we examine simultaneously the minimum and maximum level of RWA between both types of banks from year 2012 to 2016. In this study, we assume that high returns of banks affect the level of RWA within banks. We test the minimum and maximum level between both types banking system. We hypothesize that banks with maintaining the level of RWA performance within years take higher risk.

\section{Empirical Methodology}

To examine RWA by banking system, we use the following model of standardized approach:

$$
R W A=\sum_{i=1}^{N} \alpha_{i} E_{i}+\sum_{j=1}^{M} w_{j} C_{j}
$$

Where, $N=$ Number of on-balance sheet items, $\alpha_{i}=$ Risk weight of the i-th items, $E_{i}=$ Principal amount of the i-th items, $M=$ Number of off-balance sheet items, $w_{j}=$ Risk weight of the j-th items, $C_{j}=$ Credit equivalent amount of the j-th items.

To extent this further, RWA create the denominator of the risk-based capital ratio. The standardized approach to calculating RWA involves multiplying the amount of an asset by the standardized risk weight (in percentage) associated with that type of asset at high level. Higher risk weight fallouts in a higher RWA total which it gives increase to a lower risk-based capital ratio. Following is the model equation of risk-based capital ratio as it is the ratio of its regulatory capital to RWA:

$$
\text { Risk Based Capital Ratio }(\%)=\frac{\text { Regulatory Capital }}{R W A}
$$

Further, in this approach we use the following weight as such is provided by regulator:

\begin{tabular}{lccccccc}
\hline & AAA/AA- & A+/A- & BBB+/BBB- & BB+/BB- & B+/B- & Below B- & Unrated \\
\hline Countries & $0 \%$ & $20 \%$ & $50 \%$ & $100 \%$ & $100 \%$ & $150 \%$ & $100 \%$ \\
Banks & $20 \%$ & $50 \%$ & $50 \%$ & $100 \%$ & $100 \%$ & $150 \%$ & $50 \%$ \\
Corporations & $20 \%$ & $50 \%$ & $100 \%$ & $100 \%$ & $150 \%$ & $150 \%$ & $100 \%$ \\
\hline
\end{tabular}

\section{Data and Summary Statistics}

\subsection{Database}

Our sample covers Islamic and conventional banks operating in Malaysia and covers the period from 2012 to 2016. Our sample consists of 15 selected Islamic banks and 15 selected conventional banks includes of foreign and local banks.

\subsection{Summary Statistics}

Figure 1 and 2 presents the total RWA from year 2012 to 2016 for different types of banking system in Malaysia. The figure shows clear differences between Islamic and conventional banks. In mean, different types of banks produce slightly up-and-down grid within 5 years. Size of banks also gives impact towards total of RWA within banks.

In the Results section, summarize the collected data and the analysis performed on those data relevant to the discourse that is to follow. Report the data in sufficient detail to justify your conclusions. Mention all relevant results, including those that run counter to expectation; be sure to include small effect sizes (or statistically nonsignificant findings) when theory predicts large (or statistically significant) ones. Do not hide uncomfortable results by omission. Do not include individual scores or raw data with the exception, for example, of single-case designs or illustrative examples. In the spirit of data sharing (encouraged by APA and other professional associations and sometimes required by funding agencies), raw data, including study characteristics and indivldual effect sizes used in a meta -analysis, can be made available on supplemental online archives. 


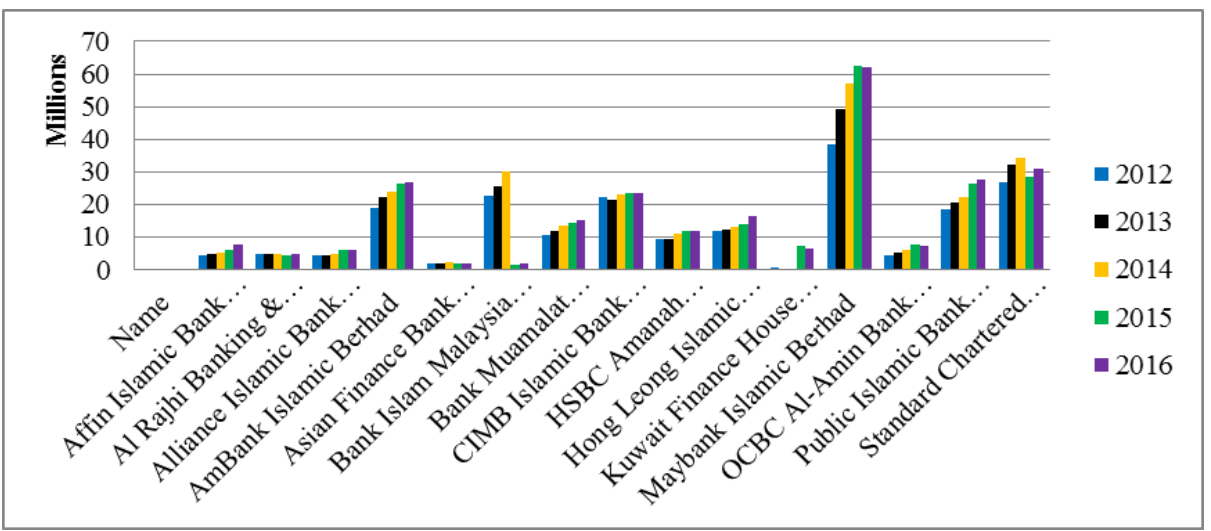

Figure 1. Conventional banks

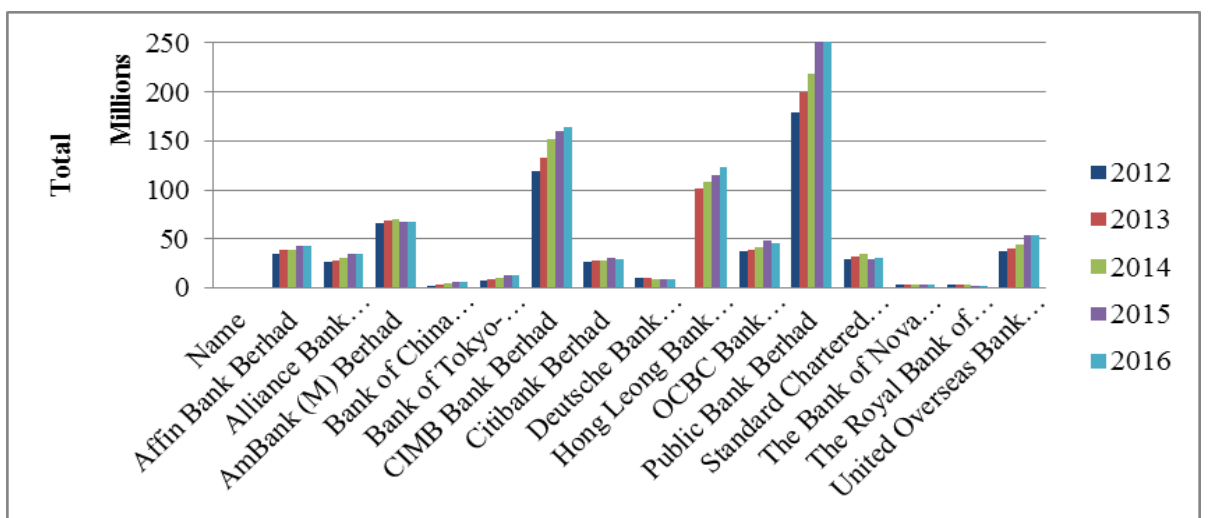

Figure 2. Islamic banks

\section{Empirical Results and Analysis}

We start by explaining the performance of RWA and it average between Islamic banks and Conventional banks. The estimation results are reported in figure 3 and 4 respectively. The estimation of the performance shows that conventional banks have better performance of RWA after the recent global financial crisis. The impact appears more important for Islamic banks.

This result confirms our initial hypothesis that Islamic banks take higher risks compared to conventional banks. The lower in RWA increases significantly bank's risks taken. This finding is consistent with the hypothesis and supports that banks with high value in RWA take lower risk because they prefer to hold safer assets in their portfolios. It is confirm that Islamic banks prefer risk-sharing compared transfer the risks.

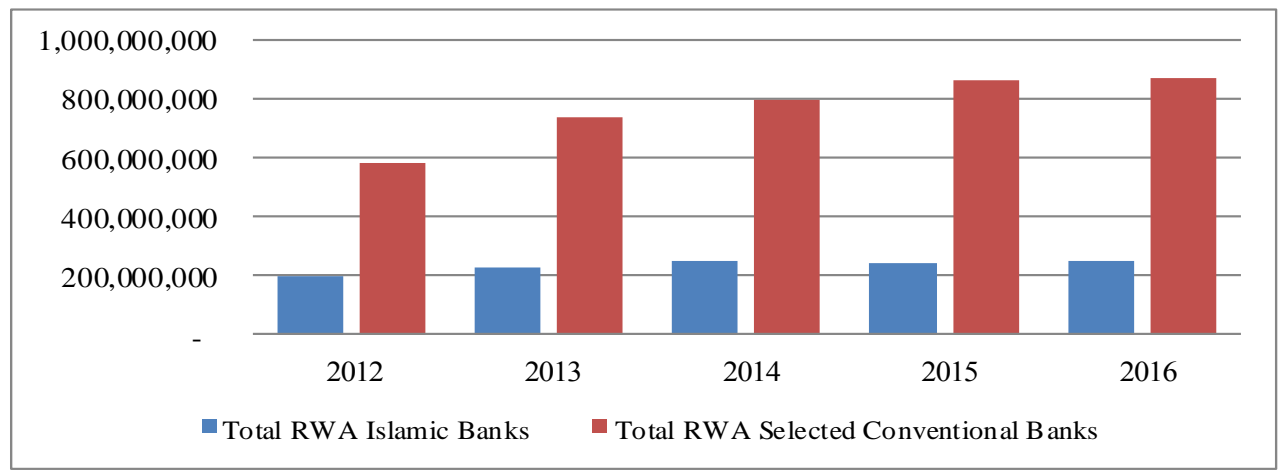

Figure 3. RWA performance within recent five (5) years (2012-2016) 


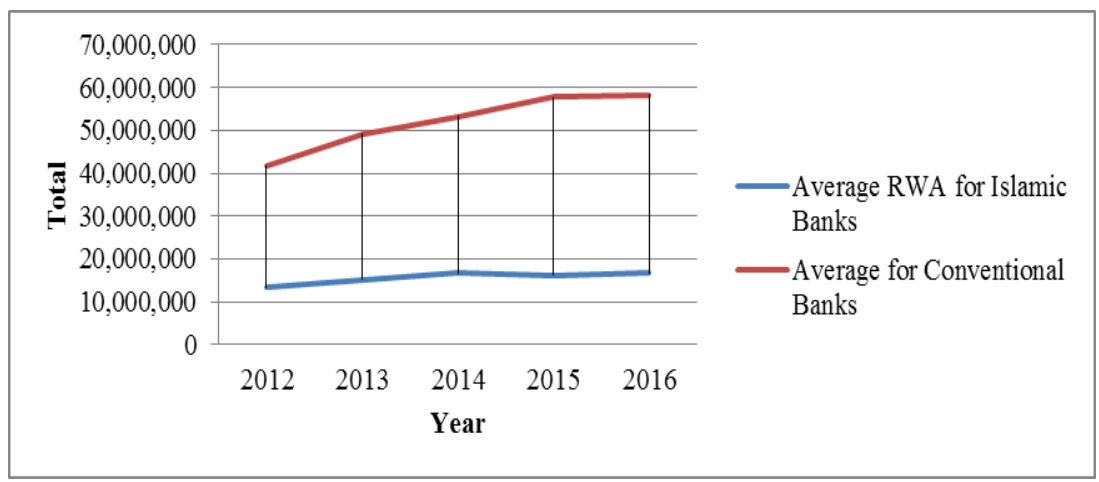

Figure 4. Average RWA between Islamic banks and Conventional banks

\section{Conclusion}

In this paper, we discuss RWA by examining the RWA performance after recent global financial crisis in Malaysian banking system. We find evidence of a relationship between RWA and risk-taking in different types of banking system. Our result suggests that high risk-taking do influence the RWA performance. The estimation of the performance shows that conventional banks have better performance of RWA after the recent global financial crisis. The impact appears more important for Islamic banks.

In the future research, we select the bank samples for examining and comparing their differences on the RWA efficiency and the capital adequacy ratio between different approaches of banking system. However, any future study should refer to previous studies to select the suitable input and output factors.

\section{Acknowledgments}

Financial support for this study was provided by a grant from the Ministry of Education Malaysia under the Grant No: USIM/FRGS/FEM/32/52314.

\section{References}

Al-Hares, O. M., AbuGhazaleh, N. M., \& El-Galfy, A. M. (2013). Financial performance and compliance with Basel III capital standards: Conventional vs. Islamic banks. Journal of Applied Business Research, 29(4), 1031-1048. https://doi.org/10.19030/jabr.v29i4.7914

Beck, T., Demirg-Kunt, A., \& Merrouche, O. (2013). Islamic vs. conventional banking: Business model. efficiency and stability. Journal of Banking and Finance, 37(2), 433-447. https://doi.org/10.1016/j.jbankfin.2012.09.016

Chazi, A., \& Syed, L. A. M. (2010). Risk exposure during the global financial crisis: the case of Islamic banks. International Journal of Islamic and Middle Eastern Finance and Management, 3(4), 321-333. https://doi.org/10.1108/17538391011093261

Das, S., \& Sy, A. N. R. (2012). How Risky Are Banks' Risk Weighted Assets? Evidence from the Financial Crisis. IMF Working Papers, 1-38. https://doi.org/10.5089/9781475511833.001

Gallati, R. (2003). Risk Management and Capital Adequacy. McGraw-Hill Education.

Kassim, H. S., \& Abd. Majid, M. S. (2010). Impact of financial shocks on Islamic banks: Malaysian evidence during 1997 and 2007 financial crises. International Journal of Islamic and Middle Eastern Finance and Management, 3(4), 291-305. https://doi.org/10.1108/17538391011093243

Lessambo, F. I. (2013). The International Banking System: Capital Adequacy, Core Businesses and Risk Management. Palgrave Macmillan.

Louati, S., Gargouri, A. I., \& Boujelbene, Y. (2015). Capital adequacy implications on Islamic and non-Islamic bank's behavior: Does market power matter? Borsa Istanbul Review, 15(3), 192-204. https://doi.org/10.1016/j.bir.2015.04.001

Martin Neisen, S. R. (2017). Basel IV: The Next Generation of Risk Weighted Assets. Wiley-VCH.

Rosman, R., Wahab, N. A., \& Zainol, Z. (2014). Efficiency of Islamic banks during the financial crisis: An analysis of Middle Eastern and Asian countries. Pacific Basin Finance Journal, 28, 76-90. https://doi.org/10.1016/j.pacfin.2013.11.001 
Sutrisno. (2016). Risk, Efficiency and Performance of Islamic Banking: Empirical Study on Islamic Bank in Indonesia. Asian Journal of Economic Modelling, 4(1), 47-56. https://doi.org/10.18488/journal.8/2016.4.1/8.1.47.56

Tabash, M. I., \& Dhankar, R. S. (2014). The Impact of Global Financial Crisis on the Stability of Islamic Banks: An Empirical Evidence. Journal of Islamic Banking and Finance, 2(1), 367-388.

\section{Copyrights}

Copyright for this article is retained by the author(s), with first publication rights granted to the journal.

This is an open-access article distributed under the terms and conditions of the Creative Commons Attribution license (http://creativecommons.org/licenses/by/4.0/). 